\title{
Helicobacter canis sp. nov., a new species from dogs: an integrated study of phenotype and genotype
}

\author{
John Stanley, ${ }^{1 *}$ Dennis Linton, ${ }^{1}$ André P. Burnens, ${ }^{3}$ Floyd E. Dewhirst, ${ }^{4}$ \\ Robert J. OWen, ${ }^{1}$ Anthony Porter, ${ }^{2}$ Stephen L. W. ON ${ }^{1}$ and Menelaos Costas ${ }^{1}$ \\ ${ }^{1,2}$ National Collection of Type Cultures ${ }^{1}$ and Virus Reference Division ${ }^{2}$, Central Public Health Laboratory, \\ 61 Colindale Avenue, London NW9 5HT, UK \\ ${ }^{3}$ Swiss National Reference Laboratory for Foodborne Diseases, Institute for Veterinary Bacteriology, \\ University of Berne, Langass-Strasse 122, CH-3012 Berne, Switzerland \\ ${ }^{4}$ Forsyth Dental Center, Department of Molecular Genetics, 140 The Fenway, Boston, MA 02115, USA
}

(Received 17 March 1993; revised 14 May 1993; accepted 20 May 1993)

\begin{abstract}
A group of Campylobacter-like organisms (CLOs) were isolated from the faeces of diarrhoeic or healthy dogs, constituting $4 \%$ of all CLOs from this source. Since they formed a unique DNA homology group within the genus Helicobacter, and exhibited distinctive phenotypic properties, they were collectively termed the $\mathrm{HC}$ group. A polyphasic taxonomic analysis was made of this group. The phenotype of four dog isolates and a single human isolate was unique and could be distinguished bacteriologically from other helicobacters. Electron microscopic ultrastructure revealed defining characteristics of Helicobacter. The 16S rRNA gene of the nominated type strain NCTC $12739^{\mathrm{T}}$ was sequenced, and its analysis delineated the group as a new species of Helicobacter. This conclusion was supported by relative DNA homology and whole-cell protein electrophoretic patterns. We therefore propose the name Helicobacter canis sp. nov. for this group. The species most closely related to $H$. canis sp. nov. were $\boldsymbol{H}$. cinaedi, 'Flexispira rappini' and $\boldsymbol{H}$. fennelliae. A species-specific recombinant DNA probe was cloned from NCTC $12739^{\mathrm{T}}$ for use in routine laboratory identification and epidemiological studies. The faecal source, bile tolerance and lack of urease activity of $\boldsymbol{H}$. canis sp. nov. suggest that this new Helicobacter species colonizes the lower bowel rather than the stomach.
\end{abstract}

\section{Introduction}

The genus Helicobacter currently includes eight named species. It forms a distinct rRNA homology group within superfamily VI, which also includes the genera Campylobacter and Arcobacter (Vandamme et al., 1991). The first-described member was $H$. pylori, a microaerophilic Gram-negative spiral organism (Warren \& Marshall, 1983) associated with human gastritis and peptic ulcers (Blaser, 1990). Four other species have been isolated

*Author for correspondence. Tel. +44812004400 ext. 3738; fax +44812007874 .

Abbreviations: CLO, Campylobacter-like organism; HC, Helicobacter, canine (group).

The GenBank accession number for the 16S rRNA gene sequence of NCTC $12739^{\mathrm{T}}$ is L13464. The accession numbers for reference organisms included in the 16S rRNA phylogenetic analysis are given in Table 1. from the gastric mucosa of animal hosts: $H$. mustelae from ferrets (Fox et al., 1986, 1989; Goodwin et al., 1989), H. felis from cats and dogs (Lee et al., 1988; Paster et al., 1991b), $H$. nemestrinae from macaque monkeys (Brondson et al., 1991) and $H$. acinonyx from cheetahs (Eaton et al., 1991, 1993). All except $H$. nemestrinae have been causally associated with gastritis of their animal host. Three species of Helicobacter appear to colonize the lower bowel of their host, rather than the gastric mucosa. These are $H$. muridarum, which was isolated from the intestinal mucosa of rodents (Lee et al., 1992), and $H$. cinaedi and $H$. fennelliae, which were isolated from humans (Fennell et al., 1984; Totten et al., 1985; Vandamme et al., 1991).

A single isolate identified in the same studies as $H$. cinaedi and $H$. fennelliae could be differentiated from them on the basis of total DNA homology, and was termed 'Campylobacter-like organism' (CLO) 3 (Fennell et al., 1984; Totten et al., 1985). Vandamme et al. (1991) placed strain 'CLO-3' in homology group III of rRNA 
superfamily VI, which includes Helicobacter species, but no further isolates have been reported and no species designation has been made. A species originally named as 'Flexispira rappini' (Bryner, 1987) may also be a true Helicobacter, according to rRNA cistron similarity (Vandamme et al., 1991) and 16S rRNA gene sequencing (Lee et al., 1992). The phylogenetic analysis of 16S rRNA gene sequences suggests that several potential new species of Helicobacter exist in avian and mammalian hosts (Paster et al., 1991a).

Special isolation media and conditions have been employed to study carriage of CLOs in domestic pet animals (Burnens et al., 1992; Burnens \& Nicolet, 1992). One thousand dogs were screened in this way and fifteen strains, $4 \%$ of the total CLOs isolated, constituted a unique DNA homology group exhibiting weak homology with $H$. fennelliae and $H$. cinaedi only. The strains were unable to reduce nitrate and were resistant to polymyxin B. Since the latter phenotype distinguishes Helicobacter spp. from Campylobacter spp. (Burnens \& Nicolet, 1993), they were provisionally termed the HC (Helicobacter, canine) group. In a parallel analysis of children with infectious gastroenteritis, one isolate was recovered which exhibited the phenotypic and DNA homology relationships of the HC group (Burnens et al., 1993).

Here we present a polyphasic taxonomic study of representative strains (four dog, one human) which establishes the HC group to be a new species of Helicobacter, for which we propose the name Helicobacter canis sp. nov.

\section{Methods}

Bacterial strains and culture conditions. Bacterial strains are listed in Table 1. Helicobacter spp., Campylobacter spp., 'Flexispira rappini', Arcobacter cryaerophila and Arcobacter butzleri were cultured on 5\% (v/v) horse blood agar plates in a Variable Atmosphere Incubator (Don Whitley Scientific). This maintained a microaerobic atmosphere of $5 \% \mathrm{O}_{2} / 5 \% \mathrm{CO}_{2} / 2 \% \mathrm{H}_{2} / 88 \% \mathrm{~N}_{2}$ at $37^{\circ} \mathrm{C}$. Arcobacter nitrofigilis was grown microaerobically in a gas jar at $25^{\circ} \mathrm{C}$. Wolinella succinogenes and [Bacteroides] ureolyticus were grown anaerobically on modified brain heart infusion agar (Malnick et al., 1990) at $37^{\circ} \mathrm{C}$ in an anaerobic cabinet (Don Whitley Scientific).

Phenotypic characterization, electron microscopy and protein electrophoresis. The phenotype of the isolates was determined by employing previously described methods and media (Holmes et al., 1992; On \& Holmes, 1991 $a, b, 1992$ ). Additional tests were performed as follows. Production of extracellular deoxyribonuclease (DNAase) was determined by the method of Lior \& Patel (1987). Growth on $1.5 \%$ bile medium [5\% blood agar to which $1.5 \%$ desiccated ox-bile (Oxoid) had been added prior to sterilization by autoclaving], and MacConkey agar (formulation CM-7, Oxoid) were determined by using inoculation and incubation methods previously described (On \& Holmes, 1991 $a, b$ ). The colonial morphology of the isolates was recorded after $3 \mathrm{~d}$ microaerobic incubation on $5 \%$ horse blood agar at $37^{\circ} \mathrm{C}$. All tests were performed in triplicate, on separate occasions, and with freshly prepared media. Electron microscopy was carried out as previously described (Stanley et al., 1992). Protein samples were prepared, run on SDS-PAGE gels, dried and analysed as described previously (Costas, 1992).

Nucleic acid techniques. Genomic DNA preparation, Southern blots and hybridization, DNA-DNA slot-blot hybridization and its analysis by laser densitometry, and cloning of a species-specific DNA probe were done as previously described (Stanley et al., 1992). The mol \% $\mathrm{G}+\mathrm{C}$ content was determined by the method of Owen \& Pitcher (1985).

Polymerase chain reaction (PCR) amplification of a $1500 \mathrm{bp}$ fragment of the 16S rRNA gene of NCTC $12739^{\mathrm{T}}$ was done as follows. Fifty nanograms of genomic DNA was subjected to PCR in a final reaction mixture $(100 \mu \mathrm{l})$ containing: $10 \mathrm{mM}-\mathrm{Tris} / \mathrm{HCl}(\mathrm{pH} 83)$; $200 \mu \mathrm{M}$-dNTPs; $0.4 \mu \mathrm{M}$ of each primer (forward primer 5 -AAGAGTTTGATCCTGGCTCAG- ${ }^{\prime}$ ' and reverse primer 5'-GGTTACCTTGTTACGACTT-3'); $1.5 \mathrm{mM}^{-\mathrm{MgCl}_{2}} ; 50 \mathrm{mM}-\mathrm{KCl} ; 0.1 \mathrm{mg}$ gelatine $\mathrm{ml}^{-1}$ and 2.5 units Taq DNA polymerase (Boehringer Mannheim). Samples were overlaid with $100 \mu \mathrm{l}$ mineral oil and subjected to 35 cycles of amplification on a PCR Heating Block (Hybaid) with the following cycling conditions: denaturation, $93^{\circ} \mathrm{C}, 1 \mathrm{~min}$; annealing, $55^{\circ} \mathrm{C}$, $1 \mathrm{~min}$; and extension, $72^{\circ} \mathrm{C}, 3 \mathrm{~min}$. The initial cycle, prior to the addition of Taq polymerase, included 5 min denaturation at $95^{\circ} \mathrm{C}$. The final cycle continued primer extension for $8 \mathrm{~min}$. After removal of mineral oil, the amplification product was purified by the method of Kusukawa et al. (1990) and nucleotide sequencing of the amplified gene was carried out following the method of Embley (1991). Products were analysed on standard wedge-shaped sequencing gels (Pharmacia LKB Macrophor apparatus). Gels were fixed in aqueous methanol/acetic acid/glycerol (10\%:5\%:2\%, by vol.), dried at $80^{\circ} \mathrm{C}$ and autoradiographed on Kodak XAR5 film.

Phylogenetic analysis of $16 S r R N A$ gene sequence information. The 16S rRNA gene sequence for NCTC $12739^{\mathrm{T}}$ was entered into RNA, a program for analysis of 16S rRNA data written in Microsoft QuickBASIC for use on IBM-PC compatible computers, and aligned as previously described (Paster \& Dewhirst, 1988). The database contains approximately 50 Helicobacter, Wolinella, Arcobacter and Campylobacter sequences and 300 sequences for other eubacteria. Similarity matrices were constructed from aligned sequences by using only those base positions for which $90 \%$ of the strains had data. The similarity matrices were corrected for multiple base changes by the method of Jukes \& Cantor (1969). Phylogenetic trees were constructed by the neighbour-joining method (Saitou \& Nei, 1987).

\section{Results}

\section{Phenotypic characterization}

In total, 34 phenotypic tests were performed on five strains of the $\mathrm{HC}$ group in order to arrive at a defining phenotype. The following six tests were reproducibly positive for these strains: production of cytochrome oxidase, growth at $37^{\circ} \mathrm{C}$, growth at $42^{\circ} \mathrm{C}$, growth on media containing 5-fluorouracil $\left(100 \mathrm{mg} \mathrm{l}^{-1}\right)$, and growth on media containing either $1 \%$ or $1.5 \%$ bile. All strains failed to produce urease or catalase (although two strains, NCTC 12741 and NCTC 12743, exhibited a weak catalase reaction). They did not produce DNAase, or hydrogen sulphide from triple sugar iron (TSI) medium. Neither nitrate nor selenite was reduced. Hippurate was not hydrolysed. Growth was not found 
Table 1. Bacterial strains

\begin{tabular}{|c|c|c|c|c|}
\hline Bacterium & Strain no. & Reference/comment & Source & $\begin{array}{c}\text { Genbank } \\
\text { no.* }\end{array}$ \\
\hline $\begin{array}{l}\text { Helicobacter } \\
\text { H. pylori } \\
\text { H. pylori } \\
\text { H. felis } \\
\text { H. felis } \\
\text { H. mustelae } \\
\text { H. acinonyx } \\
\text { H. cinaedi } \\
\text { H. fennelliae } \\
\text { H. nemestrinae } \\
\text { H. muridarum } \\
\text { HC group } \\
\text { (H. canis sp. nov.) }\end{array}$ & $\begin{array}{l}\text { NCTC } 11638 \\
\text { NCTC } 11637 \\
\text { NCTC } 12436 \\
\text { DS3 } \\
\text { NCTC } 12435 \\
\text { NCTC } 12686 \\
\text { NCTC } 12423 \\
\text { NCTC } 11612 \\
\text { NCTC } 12491 \\
\text { NCTC } 12714 \\
\text { NCTC } 12739 \\
\text { NCTC } 12741 \\
\text { NCTC } 12743 \\
\text { CCUG } 19561 \\
\text { NCTC } 12740\end{array}$ & $\begin{array}{l}\text { Reference strain } \\
\text { Type strain } \\
\text { Type strain } \\
\text { Paster } \text { et al. }(1991) \\
\text { Type strain } \\
\text { Type strain } \\
\text { Type strain } \\
\text { Type strain } \\
\text { Type strain } \\
\text { Type strain } \\
\text { Type strain } \\
- \\
- \\
- \\
-\end{array}$ & $\begin{array}{l}\text { Human } \\
\text { Human } \\
\text { Cat } \\
\text { Dog } \\
\text { Ferret } \\
\text { Cheetah } \\
\text { Human } \\
\text { Human } \\
\text { Monkey } \\
\text { Rat } \\
\text { Dog } \\
\text { Dog } \\
\text { Dog } \\
\text { Dog } \\
\text { Human }\end{array}$ & $\begin{array}{c}\text { M88157 } \\
- \\
\text { M37642 } \\
\text { M37643 } \\
\text { M35048 } \\
\text { M88148 } \\
\text { M88150 } \\
\text { M88154 } \\
- \\
\text { M80205 } \\
\text { L13464 } \\
- \\
- \\
- \\
-\end{array}$ \\
\hline $\begin{array}{l}\text { Campylobacter } \\
\text { C. fetus subsp. fetus } \\
\text { C. fetus subsp. venerealis } \\
\text { C. coli } \\
\text { C. jejuni subsp. jejuni } \\
\text { C. jejuni subsp. doylei } \\
\text { C. lari } \\
\text { C. upsaliensis } \\
\text { C. hyointestinalis } \\
\text { C. mucosalis } \\
\text { C. sputorum subsp. faecalis } \\
\text { C. sputorum subsp. bubulus } \\
\text { C. sputorum subsp. bubulus } \\
\text { C. sputorum subsp. sputorum } \\
\text { C. concisus } \\
\text { C. curvus } \\
\text { C. rectus } \\
\text { C. helveticus }\end{array}$ & $\begin{array}{l}\text { NCTC } 10842 \\
\text { NCTC } 10354 \\
\text { NCTC } 11366 \\
\text { NCTC } 11351 \\
\text { NCTC } 11951 \\
\text { NCTC } 11352 \\
\text { NCTC } 11541 \\
\text { NCTC } 11608 \\
\text { NCTC } 11000 \\
\text { NCTC } 11415 \\
\text { ATCC } 33491 \\
\text { NCTC } 11367 \\
\text { NCTC } 11528 \\
\text { NCTC } 11485 \\
\text { NCTC } 11649 \\
\text { NCTC } 11489 \\
\text { NCTC } 12470\end{array}$ & $\begin{array}{l}\text { Type strain } \\
\text { Type strain } \\
\text { Type strain } \\
\text { Type strain } \\
\text { Type strain } \\
\text { Type strain } \\
\text { Type strain } \\
\text { Type strain } \\
\text { Type strain } \\
\text { Reference strain } \\
\text { Smibert (1980) } \\
\text { Type strain } \\
\text { Type strain } \\
\text { Type strain } \\
\text { Type strain } \\
\text { Type strain } \\
\text { Type strain }\end{array}$ & $\begin{array}{l}\text { Sheep } \\
\text { Cattle } \\
\text { Pig } \\
\text { Cattle } \\
\text { Human } \\
\text { Gull } \\
\text { Dog } \\
\text { Pig } \\
\text { Pig } \\
\text { Sheep } \\
\text { Cattle } \\
\text { Cattle } \\
\text { Human } \\
\text { Human } \\
\text { Human } \\
\text { Human } \\
\text { Cat }\end{array}$ & $\begin{array}{c}\text { L04314 } \\
- \\
\text { L04312 } \\
\text { L04315 } \\
\text { L14630 } \\
\text { L04316 } \\
\text { L14628 } \\
\text { M65010 } \\
\text { L06978 } \\
- \\
\text { L04319 } \\
- \\
- \\
\text { L04322 } \\
\text { L04313 } \\
\text { L04317 } \\
-\end{array}$ \\
\hline $\begin{array}{l}\text { Arcobacter } \\
\text { A. cryaerophilus } \\
\text { A. butzleri } \\
\text { A. skirrowii } \\
\text { A. nitrofigilis }\end{array}$ & $\begin{array}{l}\text { NCTC } 11885 \\
\text { NCTC } 12400 \\
\text { NCTC } 12713 \\
\text { NCTC } 12251\end{array}$ & $\begin{array}{l}\text { Type strain } \\
\text { Type strain } \\
\text { Type strain } \\
\text { Type strain }\end{array}$ & $\begin{array}{l}\text { Cattle } \\
\text { Human } \\
\text { Sheep } \\
\text { Plant }\end{array}$ & $\begin{array}{l}\text { L14624 } \\
\text { L14626 } \\
\text { L14625 } \\
\text { L14627 }\end{array}$ \\
\hline $\begin{array}{l}\text { 'CLO-3' } \\
\text { 'Flexispira rappini' } \\
\text { Wolinella succinogenes } \\
{[\text { Bacteroides] gracilis } \dagger} \\
\text { [Bacteroides] ureolyticus } \dagger \\
\text { Escherichia coli } \\
\text { Salmonella typhimurium }\end{array}$ & $\begin{array}{l}\text { NCTC } 12462 \\
\text { NCTC } 12461 \\
\text { NCTC } 11488 \\
\text { NCTC } 12738 \\
\text { NCTC } 10941 \\
\text { FM15 } \\
\text { NCTC } 12416\end{array}$ & $\begin{array}{l}\text { (= CCUG 14564) } \\
\text { Type strain } \\
\text { Type strain } \\
\text { Type strain } \\
\text { Type strain } \\
\text { Dowling } \text { et al. } \text { (1987) } \\
\text { Type strain, subsp. } 1\end{array}$ & $\begin{array}{l}\text { Human } \\
\text { Human } \\
\text { Cattle } \\
\text { Human } \\
\text { Human } \\
\quad- \\
\quad-\end{array}$ & $\begin{array}{l}\text { M88151 } \\
\text { M88137 } \\
\text { M88159 } \\
\text { L04320 } \\
\text { L04321 } \\
\quad- \\
\quad-\end{array}$ \\
\hline
\end{tabular}

* 16S rRNA sequences for these strains are available for electronic retrieval from GenBank under the indicated accession numbers. The sequences for reference strains deposited in Genbank by F. E. Dewhirst were determined for the strains listed in this Table, but the strains were obtained from different culture collections as indicated by the accession numbers in Fig. 3.

$\dagger$ Generically misnamed. These species are not true Bacteroides but belong in rRNA superfamily VI.

under microaerobic conditions at room temperature $\left(18-22{ }^{\circ} \mathrm{C}\right.$ ), at $25^{\circ} \mathrm{C}$ or $30^{\circ} \mathrm{C}$, or under aerobic conditions. There was no growth on $0 \cdot 1 \%$ trimethylamine $\mathrm{N}$-oxide (TMAO) medium under anaerobic conditions. There was no growth on nutrient agar, on Campylobacter charcoal-desoxycholate (CCD, unsupplemented Preston base) agar, on minimal agar, on starch or on MacConkey agar media. None of the strains were tolerant to safranin ' $\mathrm{O}$ ' $(0.02 \%)$, potassium permanganate $(0 \cdot 1 \%)$, sodium arsenite $(0.001 \%)$, or to $2 \%$ and $3.5 \%(\mathrm{w} / \mathrm{v}) \mathrm{NaCl}$. Tolerance to triphenyltetrazolium chloride (TTC) was not found to be a reliable test for characterizing this 
Table 2. Principal and differential characteristics of $H$. canis and related helicobacters

Abbreviations: +, positive; -, negative; W, weak positive; M, monopolar; B, bipolar; Po, polar; Pe, peritrichous; S, sensitive; R, resistant; I, intermediate; ND, not done; $V$, variable test. $5 / 5,0 / 5$, etc., number of positive strains/number tested. Source of data, this study and Eaton et al. (1993).

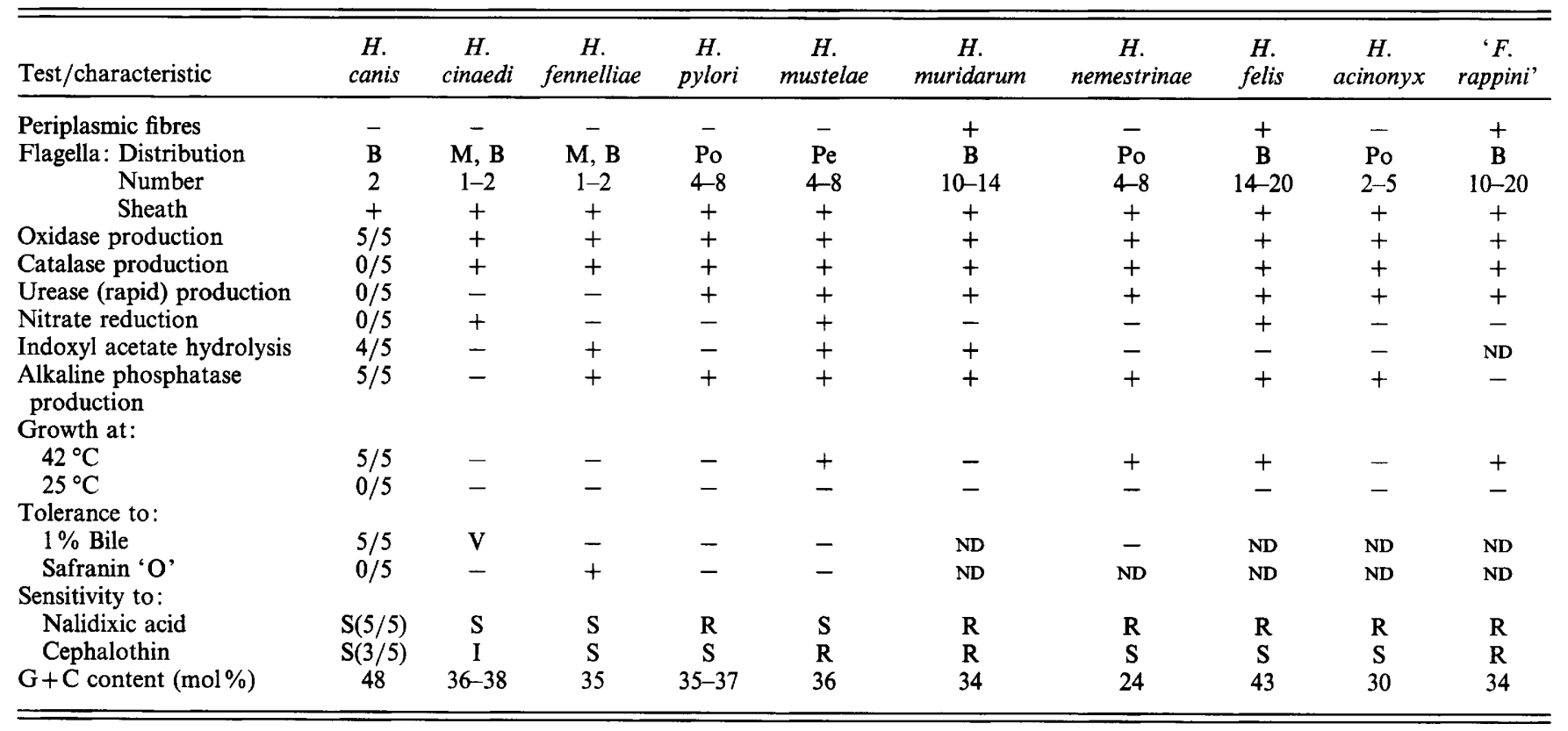

group. They were inhibited by the antibiotics nalidixic acid $\left(32 \mathrm{mg} \mathrm{ml}^{-1}\right)$, metronidazole $\left(4 \mathrm{mg} \mathrm{ml}^{-1}\right)$ and carbenicillin $\left(32 \mathrm{mg} \mathrm{m}^{-1}\right)$. All strains produced alkaline phosphatase, although NCTC 12741 exhibited a weak reaction. Strain NCTC 12743 hydrolysed indoxyl acetate, although NCTC $12739^{\mathrm{T}}$, NCTC 12740 and CCUG 19561 gave a weak reaction (visible after $20 \mathrm{~min}$ ) and NCTC 12741 failed to hydrolyse this substrate. Only NCTC 12741 and NCTC 12743 were tolerant to cephalothin $\left(32 \mathrm{mg}^{-1}\right)$. Colonial morphology on $5 \%$ horse blood agar was watery, translucent and invariably $\alpha$ haemolytic. Colony size was pinpoint and no pigments were produced. A list of characteristics useful in discriminating the $\mathrm{HC}$ group from described species of Helicobacter and 'Flexispira rappini' is given in Table 2.

\section{Ultrastructure}

Cells of NCTC $12739^{\mathrm{T}}$ were typically spiral, sometimes possessing truncated ends. Flagella were single and bipolar (Fig. 1a). They were sheathed, a defining characteristic of the genus Helicobacter, and were connected to a basal plate at the point of insertion into the cell (Fig. $1 b$ ).

\section{Whole-cell protein analysis}

One-dimensional SDS-PAGE was carried out in order to analyse whole-cell protein content and about 40 discrete bands were observed. Four HC group strains were compared with ten reference or type strains of the seven Helicobacter species, 'Flexispira rappini', Wolinella succinogenes and 'CLO-3'. Visual inspection of gels indicated that the $\mathrm{HC}$ group was homogeneous with respect to protein pattern and substantially different to other helicobacters. Numerical analysis of total protein patterns was made by calculating the correlation coefficient, and clustering was performed using the UPGMA algorithm. A rooted dendrogram representing this analysis is shown in Fig. 2. Within the HC group the banding patterns of three of the four strains were more than $90 \%$ similar. However, NCTC 12743 differed in lacking a prominent band of $37 \mathrm{kDa}$, resulting in its clustering with the other strains at the $77 \%$ similarity level. The nearest neighbour to the HC cluster was the 'CLO-3' isolate, whose banding pattern was only $47 \%$ similar. The closest defined species were $H$. cinaedi and ' $F$. rappini', whose banding patterns exhibited $45 \%$ similarity. Other Helicobacter species had patterns of less than $40 \%$ similarity.

\section{DNA base composition}

The DNA base compositions of NCTC $12739^{\mathrm{T}}$, CCUG 19561 and NCTC 12743 respectively were determined as $48 \cdot 4,48 \cdot 8$ and $48 \cdot 2 \mathrm{~mol} \% \mathrm{G}+\mathrm{C}$. 

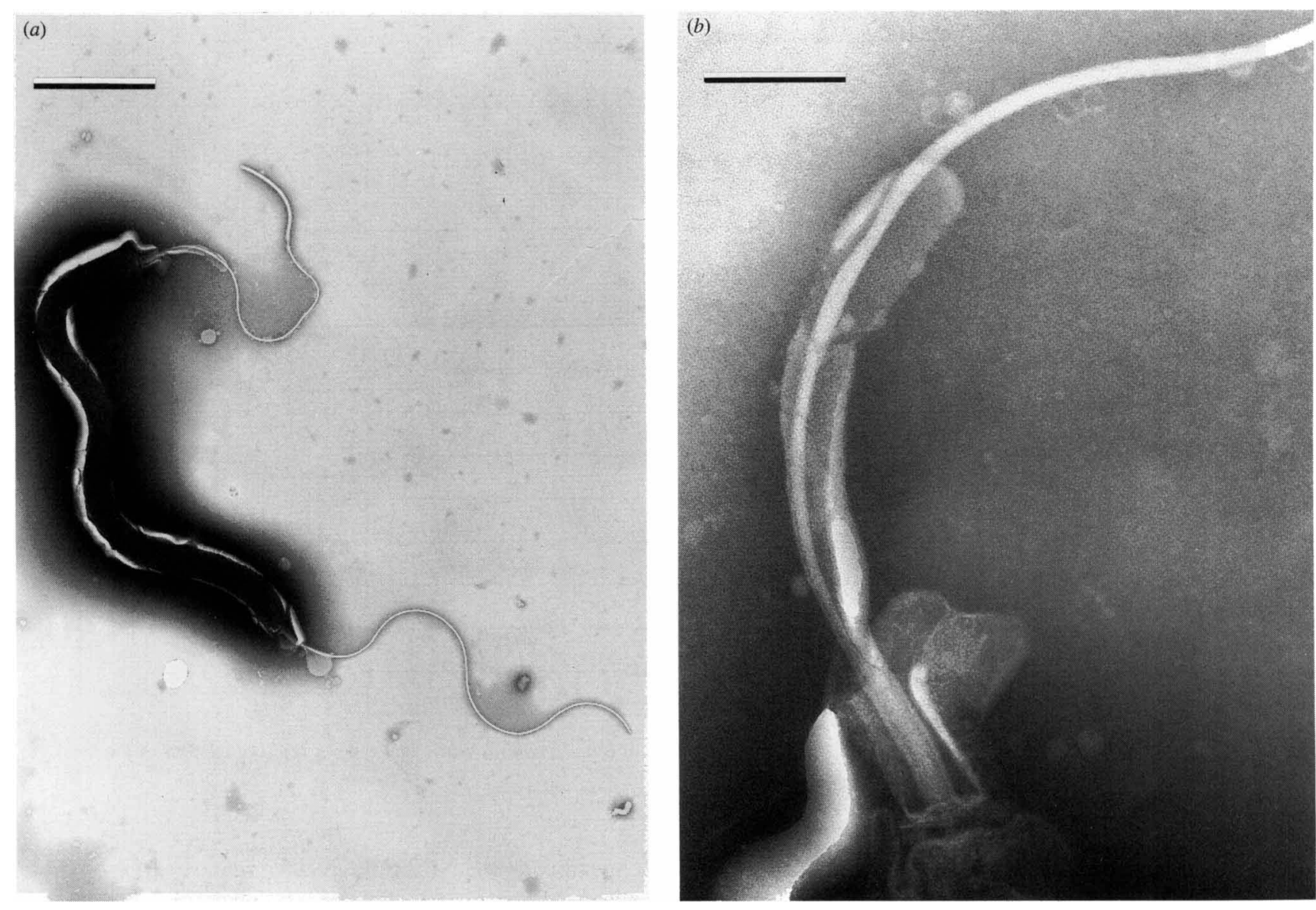

Fig. 1. (a) Electron micrograph of a single cell of $H$. canis NCTC $12739^{\mathrm{T}}$ with bipolar, partially sheathed flagella. Bar, $1000 \mathrm{~nm}$. (b) Attachment site of flagellum. Enlargement of one end of the cell shown in (a). Partial sheathing and attachment site of the flagellum are seen. Bar, $125 \mathrm{~nm}$.

\section{DNA-DNA hybridization and cloning of specific chromosomal DNA probes}

The overall genetic relatedness between the five $\mathrm{HC}$ strains and the species type strains and other reference strains representing rRNA superfamily VI (Vandamme et al., 1991) was determined by slot-blot hybridization between genomic DNAs. Theoretical aspects and taxonomic applications of this method have been discussed (Boivin et al., 1985; Lee \& McGee, 1989). DNA of NCTC $12739^{\mathrm{T}}$ was employed as a probe. No homology was detected with DNA of Salmonella typhimurium (negative control), with Wolinella succinogenes, [Bacteroides] ureolyticus, Arcobacter cryaerophilus, A . butzleri, $A$. nitrofigilis, or with any species type strain of Campylobacter (data not shown). Very low relative DNA homology was detected with $H$. felis, $H$. nemestrinae and $H$. acinonyx ( $6 \%$ each). Low homology was detected with $H$. mustelae $(10 \%)$, 'Flexispira rappini' $(11 \%)$ and $H$. pylori $(14 \%)$. Relative DNA homologies of $30 \%$ and $52 \%$ were detected with $H$. fennelliae and $H$. cinaedi respectively. The four other strains in the $\mathrm{HC}$ group exhibited more than $70 \%$ relative homology with NCTC $12739^{\mathrm{T}}$, in accordance with criteria established for the phylogenetic definition of a species (Wayne et al., 1987).

Six recombinant plasmids containing HindIII fragments cloned from NCTC $12739^{\mathrm{T}}$ (sized between 0.5 and $1.5 \mathrm{~kb}$ ) were tested for species-specific DNA homology in slot-blot hybridizations. All showed no homology with any described species of Campylobacter, Wolinella, Arcobacter, Bacteroides or Helicobacter (see Table 1) under high stringency (Stanley et al., 1992) filter-washing conditions. $\mathrm{pHCl}$, containing a cloned fragment of $1.0 \mathrm{kbp}$, was a probe suitable for the differentiation of the $\mathrm{HC}$ group from other helicobacters and their closest phylogenetic relatives (data not shown).

\section{Sequence of the 16S rRNA gene and phylogenetic analysis}

The nucleotide sequence of the 16S rRNA gene of NCTC $12739^{\mathrm{T}}$ was determined by DNA sequencing of a PCR-generated $1500 \mathrm{bp}$ fragment as described in 


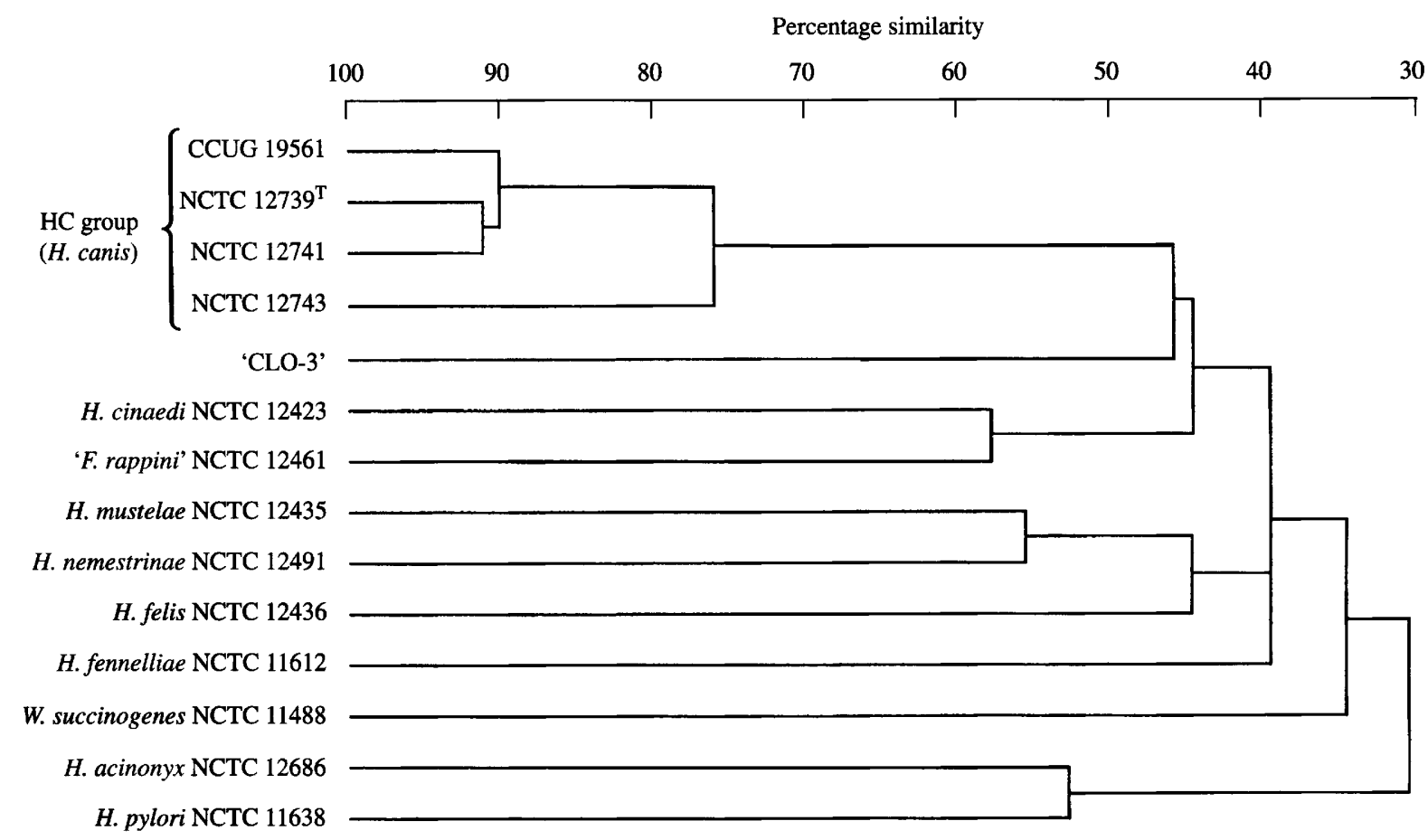

Fig. 2. Dendrogram of numerical analysis of the total protein pattern of four $H$. canis isolates, and type or reference strains of the most closely related species in rRNA superfamily VI.

Methods. Comparison of the sequence for strain NCTC $12739^{\mathrm{T}}$ with other eubacterial $16 \mathrm{~S}$ rRNA sequences in our database indicated that NCTC $12739^{\mathrm{T}}$ was closely related to species in the genus Helicobacter. The results for comparison of the 16S rRNA sequence for strain NCTC $12739^{\mathrm{T}}$ with those for 28 strains representing Helicobacter, Wolinella, Arcobacter and Campylobacter species are shown in Table 3. This matrix was based on comparisons at 1378 base positions. At each of these points, data existed for over $90 \%$ of the strains. The lower half of the matrix is expressed as percentage difference corrected for multiple base changes by the method of Jukes \& Cantor (1969). NCTC $12739^{\mathrm{T}}$ was most closely related to 'Flexispira rappini' $(98.2 \%$ similarity) and $H$. cinaedi ( $97.9 \%$ similarity).

A phylogenetic tree obtained from the corrected matrix using the neighbour joining method is shown in Fig. 3 . There were three major clusters in the phylogenetic tree. The first cluster was comprised of Campylobacter species and two generically misnamed Bacteroides species. The second cluster contained the four Arcobacter species. The third cluster was comprised of Helicobacter species, ' $F$. rappini' and Wolinella succinogenes. NCTC $12739^{\mathrm{T}}$ formed part of a Helicobacter subcluster which included $H$. cinaedi, ' $F$. rappini', $H$. muridarum and $H$. mustelae. $H$. pylori, $H$. acinonyx and $H$. felis formed a second Helicobacter subcluster. H. fennelliae and 'CLO-3' branched deeply within Helicobacter and were not part of subclusters. NCTC $12739^{\mathrm{T}}$ was clearly different $(7 \cdot 0 \%)$ from the canine isolate of $H$. felis, DS3 (Paster et al., $1991 b$ ).

\section{Discussion}

Having examined the phenotypic characteristics and phylogenetic relationships of the $\mathrm{HC}$ group we consider it to constitute a previously undescribed species of Helicobacter, for which we propose the name Helicobacter canis. The phenotypic characteristics, notably microaerophily and overall biochemical inertness, were those generally associated with Campylobacter and Helicobacter (see Table 2). The presence of sheathed flagella (Fig. 1) placed it within the genus Helicobacter (Vandamme et al., 1991). Bipolar flagella, as found in $H$. canis (Fig. 1), have also been found in $H$. cinaedi and $H$. fennelliae and their sheathing is notably similar to that of $H$. canis (Han et al., 1989). The cellular ultrastructure resembled that of $H$. pylori, and we observed no complex features such as the periplasmic fibres and multiple flagella of $H$. felis (Paster et al., 1991 b) and H. muridarum (Lee et al., 1992).

The $\mathrm{G}+\mathrm{C}$ content of the nominated type strain NCTC $12739^{\mathrm{T}}(48.4 \mathrm{~mol} \%)$ was somewhat higher than that of $\mathrm{H}$. felis $(42.5 \mathrm{~mol} \%)$, which was until now the highest reported value for the genus Helicobacter (Paster et al., 1991b). Low (6-14\%) relative DNA homology 
Table 3. Similarity matrix based on $16 S$ rRNA sequence comparisons

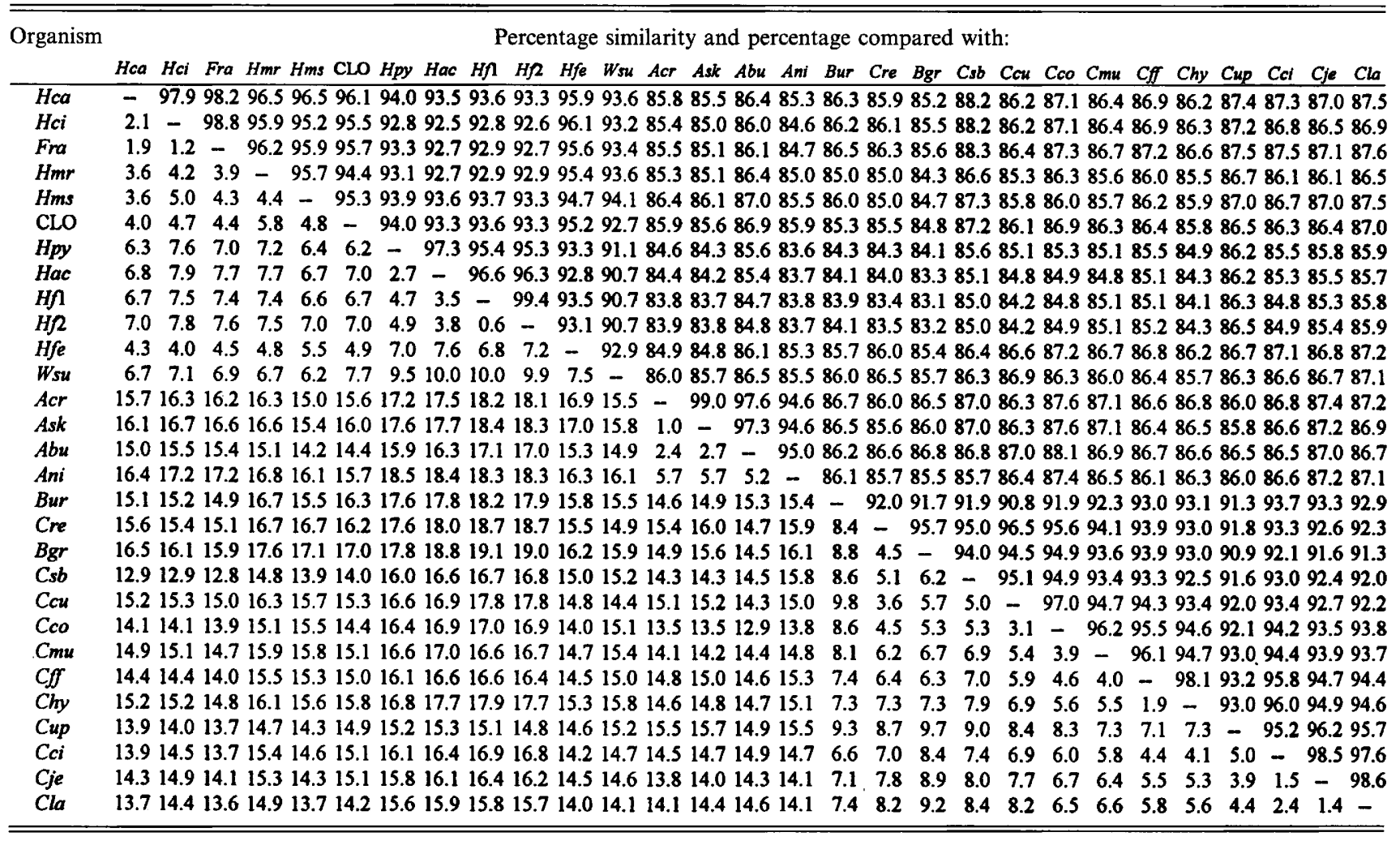

Abbreviations: Hca, H. canis; Hci, H. cinaedi; Fra, 'F. rappini'; Hmr, H. muridarum; Hms, H. mustelae; CLO, Helicobacter sp. 'CLO-3'; Hpy, H. pylori; Hac, H. acinonyx; Hf $1, H$. felis CS1; Hf 2, H. felis DS3; Hfe, H. fennelliae; Wsu, W. succinogenes; Acr, A. cryaerophilus; Ask, A skirrowii, Abu, A. butzleri, Ani, A. nitrofigilis; Bur, [B.] ureolyticus; Cre, C. rectus; Bgr, [B.] gracilis; Csb, C. sputorum subsp. bubulus; Ccu, C. curvus; Cco, C. concisus; Cmu, C. mucosalis; Cff, C. fetus subsp. fetus; Chy, C. hyointestinalis; Cup, C. upsaliensis; Cci, C. coli; Cje, C. jejuni subsp. jejuni; Cla, C. lari.

Numbers above the diagonal are uncorrected percentages of similarity. Numbers below the diagonal are percentages of difference corrected for multiple base changes by the method of Jukes and Cantor (1969).

was detected with most Helicobacter species, but values of $52 \%$ and $30 \%$ were detected with $H$. cinaedi and $H$. fennelliae respectively. It should be noted however that the $\mathrm{mol} \% \mathrm{G}+\mathrm{C}$ content of these species is quite different from $H$. canis (Table 2). The nucleotide sequence of its 16S rRNA gene identified NCTC $12739^{\mathrm{T}}$ as representative of a unique taxon within Helicobacter, whose closest phylogenetic relatives were 'Flexispira rappini' (1.9\% sequence divergence), $H$. cinaedi $(2.1 \%$ sequence divergence), $H$. muridarum and $H$. mustelae (Table 3 , Fig. 3). In an analysis of electrophoretic protein patterns (Fig. 2) $H$. canis formed a homogeneous cluster ( $\geqslant 77 \%$ level of similarity) separated from other Helicobacter species. This cluster was linked to the nearest species, $H$. cinaedi and ' $F$. rappini', at a $45 \%$ level of similarity. There are notable correspondences in the dendrograms derived from 16S rRNA gene sequence and from electrophoresis of total proteins (compare Figs 2 and 3) in the placement of $H$. canis and its nearest neighbours. Therefore there is agreement between relative genomic
DNA homology, 16S rRNA gene sequencing, cellular ultrastructure and electrophoretic protein pattern that this taxon is a novel species of Helicobacter.

$H$. canis could be bacteriologically distinguished from other Helicobacter species since it was simultaneously catalase and urease negative, and exhibited marked tolerance to bile. Its distinguishing phenotypic characteristic with respect to the most related species, $H$. cinaedi, was the inability to reduce nitrate. We compared $H$. canis with ' $\mathrm{CLO}-3$ ' because of the historical and biological association of that strain with $H$. cinaedi and $H$. fennelliae, the closest relatives of the $\mathrm{HC}$ group in our original dot-blot hybridizations. $H$. canis exhibited $4.0 \%$ 16S rrn gene sequence divergence from 'CLO-3' (Table 3 ) and $40 \%$ DNA homology with it (data not shown); these values are well beyond the limits for species separation. $H$. canis could also be distinguished from 'CLO-3' by the analysis of whole-cell protein profiles (Fig. 2). Finally, $H$. canis was sensitive to nalidixic acid, failed to produce catalase and was able to tolerate $1 \%$ 


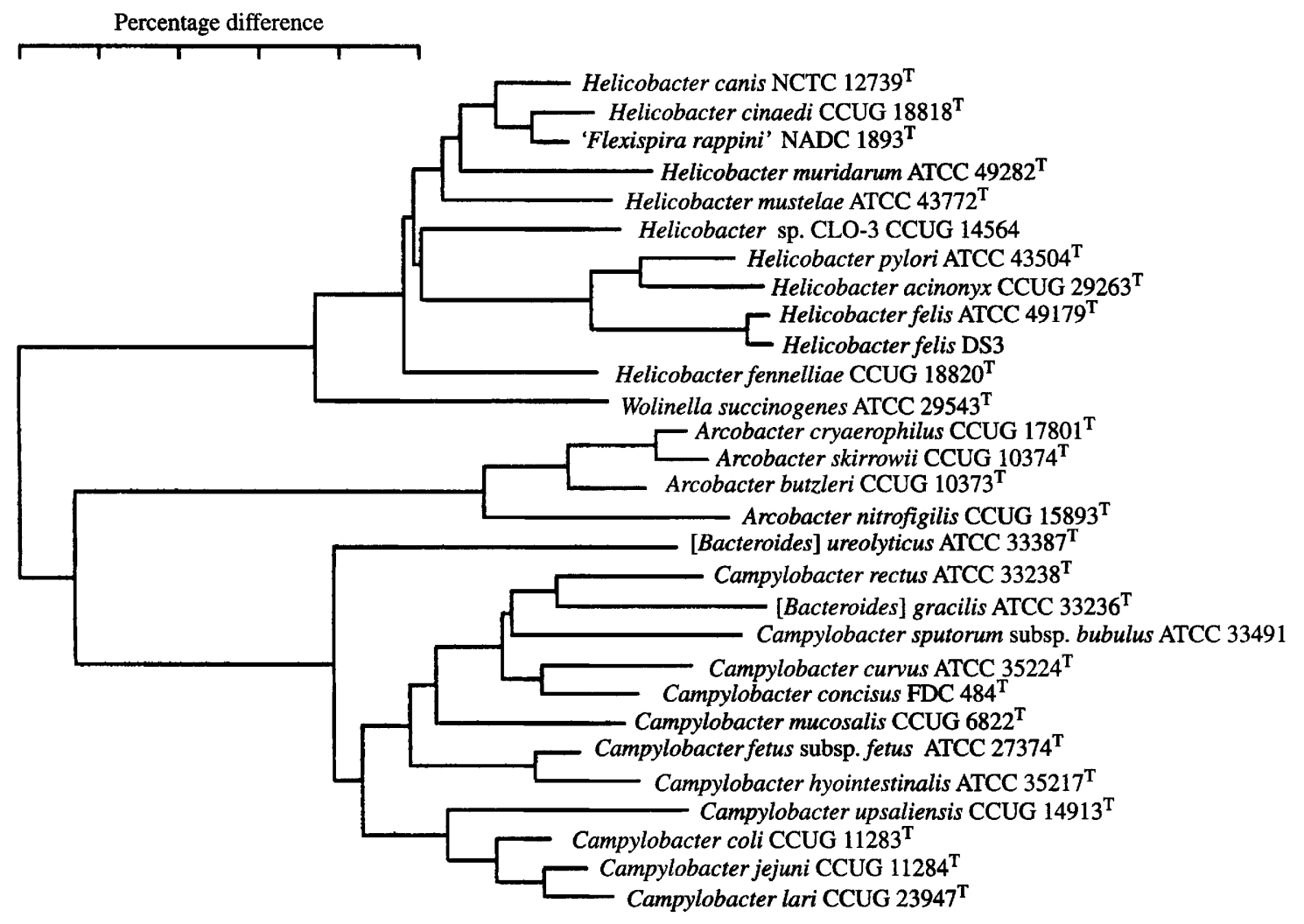

Fig. 3. Phylogenetic tree for H. canis and 28 reference Helicobacter, Wolinella, Arcobacter and Campylobacter species based on $16 \mathrm{~S}$ rRNA sequence similarity. The scale bar represents $5 \%$ difference in nucleotide sequence as determined by measuring the lengths of the horizontal lines connecting any two species. See footnote to Table 1 for an explanation of strain numbers.

bile, whilst the 'CLO- 3 ' isolate exhibited the converse results for these phenotypic tests. Results presented here (Table 3, Fig. 3) indicate that 'CLO-3' and 'F. rappini' are clearly helicobacters.

Species-specific probes are particularly useful since the bacteriological (biochemical) differentiation of Helicobacter and Campylobacter species can be difficult and laborious. The probe $\mathrm{pHCl}$ provides a means of rapid identification of $H$. canis among CLOs from diverse sources. This is important for studies of its prevalence, and potential routes of zoonotic transmission (see below) for this new species.

There was no direct association with diarrhoeal disease among the dogs from which the HC strains were isolated (A. P. Burnens, unpublished results). One strain among those examined here was from a boy with diarrhoea (Burnens et al., 1993). H. cinaedi and $H$. fennelliae were initially isolated from rectal swabs of homosexual men (Totten et al., 1985), a group in which they were separately shown to cause bacteraemias (Cimolai et al., 1987; Ng et al., 1987; Pasternak et al., 1984). H. cinaedi has also been isolated from the blood and faeces of children and adult females (Tee et al., 1987; Vandamme et al., 1990). It has been suggested that this species may have a reservoir in hamsters (Gebhart et al., 1989), and evidence has been provided that its zoonotic transmission to newborn human babies can result in sepsis and meningitis (Orlicek et al., 1993). The isolation of a single strain of $H$. canis from a human indicates that this species can colonize the human gastrointestinal tract. Further studies will be required to establish whether the prevalence of $H$. canis in domestic dogs constitutes a potential reservoir for zoonotic transmission to man. The isolation of $H$. canis from faeces, its bile tolerance and its lack of urease activity, suggest that it is an intestinal, rather than a gastric-colonizing organism. The identification of another non-gastric Helicobacter (in addition to $H$. cinaedi, $H$. fennelliae and $H$. muridarum) supports the concept that Helicobacter species might be grouped according to the specific tissues and environments with which they are associated throughout the gastrointestinal tract of animals and man. Furthermore, all the enteric helicobacters seem to be characterized by one or two polar flagella, in contrast to gastric helicobacters, which have multiple flagella (Table 2).

Formal description of $H$. canis sp. nov.

(canis, Latin noun, dog; after source of first isolation) Gram-negative, non-spore-forming, helically curved and 
slender rod-shaped cells; typically $0 \cdot 25 \times 4 \mu \mathrm{m}$. Cells have one to two spiral turns, and carry single bipolar sheathed flagella. Exhibits darting motility in hangingdrop preparations of broth cultures. Colonies pinpoint, non-pigmented, translucent and $\alpha$-haemolytic after $48 \mathrm{~h}$ on blood agar. Microaerophilic. No growth under aerobic or anaerobic conditions. No growth at $25^{\circ} \mathrm{C}$, but growth at $37^{\circ} \mathrm{C}$ and $42{ }^{\circ} \mathrm{C}$ (thermotolerant). Produces oxidase. Does not produce catalase or urease. Glucose not fermented. Hydrogen sulphide not produced in triple sugar iron medium. Neither nitrate nor selenite is reduced. Hippurate is not hydrolysed. Tolerant to $1.5 \%$ bile, but not to safranin ' $O$ '. Resistant to polymyxin B and sensitive to nalidixic acid. The $\mathrm{G}+\mathrm{C}$ content of genomic DNA by thermal denaturation is $48 \mathrm{~mol} \%$. Isolated from faeces of diarrhoeic or healthy domestic dogs. One strain has been isolated from human faeces. Pathogenicity uncharacterized.

\section{Formal description of the type strain}

NCTC $12739^{\mathrm{T}}$ is the type strain of $H$. canis. This strain conforms to the description of the species given above. The $\mathrm{G}+\mathrm{C}$ content of NCTC $12739^{\mathrm{T}}$ is $48 \mathrm{~mol} \%$. The strain was isolated in Switzerland from a domestic dog with diarrhoeal illness. Three additional strains of $H$. canis have been deposited with the National Collection of Type Cultures: NCTC 12740, NCTC 12741 and NCTC 12743.

This paper was initiated with the support of a British Council grant to John Stanley for scientific cooperation between the UK and Switzerland. We are grateful to Richard Birtles and Nick Saunders for their assistance with the set-up of PCR-based sequencing, and to Pauline Borman for assistance with culture and characterization of Helicobacter isolates.

\section{References}

BLASER, M. J. (1990). Helicobacter pylori and the pathogenesis of gastroduodenal inflammation. Journal of Infectious Diseases 161, 626-633.

Boivin, M. F., Morris, V. L., Lee-Chan, E. C. M. \& Murray, R. G. E. (1985). Deoxyribonucleic acid relatedness between selected members of the genus Aquaspirillum by slot blot hybridization: Aquaspirillum serpens (Mueller 1786) Hylemon, Wells, Krieg and Jannasch 1973 emended to include Aquaspirillum bengal as a subjective synonym. International Journal of Systematic Bacteriology $35,512-517$.

Brondson, M. A., Goodwin, C. S., Sly, L. I., Chilvers, T. \& SCHOENKNECHT, F. D. (1991). Helicobacter nemestrinae sp. nov., a spiral bacterium found in the stomach of a Pigtailed Macaque (Macaca nemestrina). International Journal of Systematic Bacteriology 41, 148-153.

BRYNER, J. H. (1987). Flexispira rappini, gen. nov., sp. nov. A motile, urease-producing rod similar to Campylobacter pyloridis. In Campylobacter IV, Proceedings of the 4th International Workshop on Campylobacter Infection, pp. 440-442. Edited by B. Kaijser \& E. Falsen. Kungälv: Goterna.

Burnens, A. P. \& NiCOleT, J. (1992). Detection of Campylobacter upsaliensis in diarrheic dogs and cats, using a selective medium with cefoperazone. American Journal of Veterinary Research 53, 48-51.

Burnens, A. P. \& Nicolet, J. (1993). Three supplementary tests for Campylobacter species and related organisms. Journal of Clinical Microbiology 31, 708-710.

Burnens, A. P., ANGeloz-Wick, B. \& Nicolet, J. (1992). Comparison of Campylobacter carriage rates in diarrheic and healthy pet animals. Zentralblatt für Veterinärmedizin 39, 175-180.

Burnens, A. P., Stanley, J., SchaAd, U. B. \& Nicolet, J. (1993). A novel Campylobacter-like organism resembling Helicobacter fennelliae isolated from a boy with gastroenteritis and from dogs. Journal of Clinical Microbiology 31, 1916-1917.

Cimolai, N., Gill, M. J., Jones, A., Flores, B., Stamm, W. E., Laurie, W., Madden, B. \& Shahrabadi, M. S. (1987). 'Campylobacter cinaedi' bacteremia: case report and laboratory findings. Journal of Clinical Microbiology 25, 942-943.

Costas, M. (1992). Classification, identification and typing of bacteria by the analysis of their one-dimensional polyacrylamide gel electrophoresis protein patterns. In Advances in Electrophoresis, vol. 5, pp. 351-408. Edited by A. Chambrach, M. J. Dunn \& B. J. Radola. Weinheim: VCH Verlagsgesellschaft.

Eaton, K. A., Radin, M. J., Fox, J. G., Paster, B., Dewhirst, F., KrakowKa, S. \& Morgan, D. R. (1991). Helicobacter acinonyx, a new species of Helicobacter isolated from cheetahs with gastritis. Microbial Ecology in Health and Disease 4 (Special Issue), S104.

Eaton, K. A., Dewhirst, F. E., Radin, M. J., Fox, J. G., Paster, B. J., KrakowkA, S. \& Morgan, D. R. (1993). Helicobacter acinony $x$ sp. nov., isolated from cheetahs with gastritis. International Journal of Systematic Bacteriology 43, 99-106.

EMBLeY, T. M. (1991). The linear PCR reaction: a simple and robust method for sequencing amplified rRNA genes. Letters in Applied Microbiology 13, 171-174.

Fennell, C. L., Totten, P. A., Quinn, T. C., Patton, D. L., Holmes, K. K. \& STAMM, W. E. (1984). Characterization of Campylobacterlike organisms isolated from homosexual men. Journal of Infectious Diseases 149, 58-66.

Fox, J. G., Edrise, B. M., Cabot, E. B., Beaucage, C., Murphy, J. C. \& ProstaK, K. S. (1986). Campylobacter-like organisms isolated from the gastric mucosa in ferrets. American Journal of Veterinary Research 47, 236-239.

Fox, J. G., Chilvers, T., Goodwin, C. S., TAylor, N. S., Edmonds, P., SLY, L. I. \& BRENNER, D. J. (1989). Campylobacter mustelae, a new species resulting from the elevation of Campylobacter pylori subsp. mustelae to species status. International Journal of Systematic Bacteriology 39, 301-303.

Gebhart, C. J., Fennel, C. L., Murtaugh, M. P. \& Stamm, W. E. (1989). Campylobacter cinaedi is normal intestinal flora in hamsters. Journal of Clinical Microbiology 27, 1692-1694.

Goodwin, C. S., Armstrong, J. A., Chilvers, T., Peters, M., Collins, M. D., Sly, L., McConnell, W. \& Harper, W. E. S. (1989). Transfer of Campylobacter pylori and Campylobacter mustelae to Helicobacter gen. nov. as Helicobacter pylori comb. nov. and Helicobacter mustelae comb. nov. respectively. International Journal of Systematic Bacteriology 39, 397-405.

HAN, Y.-H., SMiBerT, R. M. \& KRIEG, N. R. (1989). Occurrence of sheathed flagella in Campylobacter cinaedi and Campylobacter fennelliae. International Journal of Systematic Bacteriology 39, 488-490.

Holmes, B., On, S. L. W., Costas, M. \& Ganner, M. (1992). Some new applications of probabilistic identification. Proceedings of the Conference on Taxonomy and Automated Identification of Bacteria, pp. 6-8. Edited by J. Schindler. Prague: Czechoslovak Society for Microbiology.

JukES, T. H. \& CANTOR, C. R. (1969). Evolution of protein molecules. In Mammalian Protein Metabolism, vol. 3, pp. 21-132. Edited by H. N. Munro. New York: Academic Press.

Kusukawa, N., Uemori, T., Asada, K. \& Kato, I. (1990). Rapid and reliable protocol for direct sequencing of material amplified by the polymerase chain reaction. Biotechniques 9, 66-72.

LeE, A., HaZell, S. L., O'RourKe, J. \& KoupraCh, S. (1988). Isolation of a spiral-shaped bacterium from the cat stomach. Infection and Immunity 56, 2843-2850. 
Lee, A., Phillips, M. W., O'Rourke, J. L., Paster, B. J., Dewhirst, F. E., Fraser, G. J., Fox, J. G., Sly, L. I., Romaniuk, P. J., Trust, T. J. \& KoupRaCH, S. (1992). Helicobacter muridarum sp. nov., a microaerophilic helical bacterium with a novel ultrastructure isolated from the intestinal mucosa of rodents. International Journal of Systematic Bacteriology 42, 27-36.

LEE, A. S. G. \& MCGEE, J. O. (1989). The signal intensity on Southern blots developed by nonisotopic methods is linear with time and quantity of DNA. Nucleic Acids Research 17, 2364.

LIOR, H. \& PATEL, A. (1987). Improved toludine blue-DNA agar for detection of DNA hydrolysis by Campylobacters. Journal of Clinical Microbiology 25, 2030-2031.

Malnick, H., Williams, K., Phil-Ebosie, J. \& Levy, A. S. (1990). Description of a medium for isolating Anaerobiospirillum spp., a possible cause of zoonotic disease, from diarrheal feces and blood of humans and use of the medium in a survey of human, canine, and feline feces. Journal of Clinical Microbiology 28, 1380-1384.

Ng, V. L., Hadley, W. K., Fennel, C. L., Flores, B. M. \& Stamm, W. E. (1987). Successive bacteremias with 'Campylobacter cinaedi' and 'Campylobacter fennelliae' in a bisexual male. Journal of Clinical Microbiology 25, 2008-2009.

ON, S. L. W. \& Holmes, B. (1991a). Effect of inoculum size on the phenotypic characterization of Campylobacter spp. Journal of Clinical Microbiology 29, 923-926.

ON, S. L. W. \& Holmes, B. (1991 $b$ ). Reproducibility of tolerance tests that are useful in the identification of campylobacteria. Journal of Clinical Microbiology 29, 1785-1788.

ON, S. L. W. \& Holmes, B. (1992). Assessment of enzyme detection tests useful in identification of campylobacteria. Journal of Clinical Microbiology 30, 746-749.

OrLICEK, S. L., WelCh, D. F. \& KuHLS, T. L. (1993). Septicaemia and meningitis caused by Helicobacter cinaedi in a neonate. Journal of Clinical Microbiology 31, 569-571.

OWEN, R. J. \& PtTCHER, D. G. (1985). Chemical methods for estimating DNA base compositions and levels of DNA-DNA hybridization. In Chemical Methods in Bacterial Systematics, pp. 67-93. Edited by M. Goodfellow \& D. E. Minnikin. London: Academic Press.

PASTER, B. J. \& Dewhirst, F. E. (1988). Phylogeny of Campylobacters, Wolinellas, Bacteroides gracilis, and Bacteroides ureolyticus by $16 \mathrm{~S}$ ribosomal ribonucleic acid sequencing. International Journal of Systematic Bacteriology 38, 56-62.

Paster, B. J., Dewhirst, F. E., Seymour, C., Fraser, G. J. \& Fox, J. G. (1991a). Helicobacter species isolated from bird and swine feces. Microbial Ecology in Health and Disease 4 (Special Issue), S107.

Paster, B. J., Lee, A., Fox, J. G., Dewhirst, F. E., Tordoff, L. A., Fraser, G. J., O'Rourke, J. L., TAYLOR, N. S. \& Ferrero, R. (1991b). Phylogeny of Helicobacter felis sp. nov., Helicobacter mustelae, and related bacteria. International Journal of Systematic Bacteriology 41, 31-38.

Pasternak, J., Bolivar, R., Hopfer, R. L., Fainstein, V., Mills, K., Rios, A., Bodey, G. P., Fennell, C. L., Totten, P. A. \& Stamm, W. E. (1984). Bacteremia caused by Campylobacter-like organisms in two male homosexuals. Annals of Internal Medicine 101, 339-341.

SAITou, N. \& NEI, M. (1987). The neighbour-joining method: a new method for reconstructing phylogenetic trees. Molecular Biology and Evolution 4, 406-425.

Stanley, J., Burnens, A. P., Linton, D., On, S. L. W., Costas, M. \& Owen, R. J. (1992). Campylobacter helveticus sp. nov., a new thermophilic species from domestic animals: characterization and cloning of a species-specific DNA probe. Journal of General Microbiology 138, 2293-2303.

Tee, W., Anderson, B. N., Ross, B. C. \& Dwyer, B. (1987). Atypical campylobacters associated with gastroenteritis. Journal of Clinical Microbiology 25, 1248-1252.

Totten, P. A., Fennell, C. L., Tenover, F. C., Wezenberg, J. M., Perine, P. L., Stamm, W. E. \& Holmes, K. K. (1985). Campylobacter cinaedi (sp. nov.) and Campylobacter fennelliae (sp. nov.): two new Campylobacter species associated with enteric disease in homosexual men. Journal of Infectious Diseases 151, 131-139.

Vandamme, P., Falsen, E., Pot, B., Kersters, K. \& De Ley, J. (1990). Identification of Campylobacter cinaedi isolated from blood and feces of children and adult females. Journal of Clinical Microbiology 28, 1016-1020.

Vandamme, P., Falsen, E., Rossau, R., Hoste, B., Segers, P., Tytgat, R. \& De LEY, J. (1991). Revision of Campylobacter, Helicobacter, and Wolinella taxonomy: emendation of generic descriptions and proposal of Arcobacter gen. nov. International Journal of Systematic Bacteriology 41, 88-103.

WARREN, R. J. \& MARSHALl, B. (1983). Unidentified curved bacilli on gastric epithelium in active chronic gastritis. Lancet $\mathbf{i}, 1273-1275$.

Wayne, L. J., Brenner, D. J., Colwell, R. R., Grimont, P. A. D., Kandler, O., KRIChEVSKy, M. I., MoORE, L. H., MOORE, W. E. C., Murray, R. G. E., Stackebrandt, E., Starr, M. P. \& TrüPer, H. G. (1987). Report of the ad hoc committee on reconciliation of approaches to bacterial systematics. International Journal of Systematic Bacteriology 37, 463-464. 